\title{
Skills training through hands-on practical activities in civil technology - a case study of three technical schools in South Africa
}

\author{
MSA MAEKO' AND M MAKGATO2
}

\begin{abstract}
Skills training for Civil Technology learners in South African schools, is an aspect entrenched in the Civil Technology policy document in order to produce skilled personnel for a sustainable economy. Practical activities through the Practical Assessment Task (PAT) are national requirements for all practical-based subjects from grades 10-12 in South African schools. The purpose of this study was to investigate the status of Civil Technology practical activities in three South African schools in the Eastern Cape Province. Purposive sampling was used to identify 41 learners and 3 teachers to participate in the study. Questionnaires, semi-structured interviews and observation as data collection methods were instruments used to collect data. The study has found that learners exit grade 12 without basic practical hands-on skills. Civil Technology practical activities were found to be inadequately offered in the three schools investigated. Educators should be well-trained by higher education institutions (HEIs) to conduct practical activities with learners so that these learners are equipped with marketable skills in order to contribute to a sustainable economy after grade 12. Technology teacher education and training should include regular exposure and visits to relevant industries in order for teachers to keep abreast with the latest technological developments. The supply of equipment to schools should be coupled with routine maintenance of the equipment.
\end{abstract}

Keywords: Practical skills acquisition, Civil Technology, skills training, Eastern Cape, practical activities

Discipline: Technology education

\section{Introduction}

Post-apartheid South Africa provided the Ministry of Education with the opportunity to change the curriculum; one of the new subjects conceived for secondary schools, was Civil Technology, previously known as Woodworking. Woodworking fell within Technical Education currently called Technology Education and included trades such as plumbing, bricklaying and plastering that were taught separately. Learners who studied the subject would be apprenticed, obtain a trade test certificate then become artisans and entrepreneurs whereby they earned a living if they were unable to further their studies. Usually apprentices complete a trade test at the end of their training at the Institute for the Development of Learnerships and Learnership Assessment (INDLELA), after which they are certified if successful and recognized as artisans within the relevant industries (Department of Labour, 1998). The subject Civil Technology is designed to provide learners with a sound technical foundation that integrates both theory and practical competencies (Department of Education,

1. Mr Mogale Maeko is a lecturer at the Durban University of Technology in Civil technology in teacher education. Email: maekos@dut.ac.za

2. Prof. Moses Makgato is an associate professor at Tshwane University of Technology. His research interests include Technology education, Educational technology/ ICT in education, Technical Vocational Education and Training. Email address: makgatom@tut.ac.za 
2005). According to the curriculum assessment policy statement (CAPS) (Department of Basic Education, 2011), learners who study Civil Technology in grades 10-12 will acquire skills that will make it easy for them to enter into learnerships or apprenticeships in preparation for a trade test. The CAPS document (DBE, 2011) lists, among other things, the workshop with tools and equipment together with measuring equipment and consumable items as the basic requirements to achieve this objective. Kennedy (2011) states that since the Civil Technology course is intended to be practically oriented, fewer theory than practical components should be taught. The purpose of this study was to investigate the status of Civil Technology practical activities in three South African schools in the Eastern Cape Province.

\section{Civil Technology in schools}

The school system, through technical schools and through technology education subjects in academic schools, has been contributing to skills development for many years (McGrath, 1998). Learners in South African schools study Civil Technology only from grade 10 to grade 12 where the practical component should be implemented. According to the policy document (DBE, 2011), the subject Civil Technology is allocated four hours per week of which $2 \frac{1}{2}$ hours are for teaching theory and $1 \frac{1 / 2}{2}$ hours for practical lessons. According to Brunette (2006), technology subjects must include practical work, because applying theory to practice provides the practical experience that is necessary. In this study, Brunette discovered that, unfortunately, schools had been producing many learners without technical skills. Technology education is viewed as education which equips learners with marketable skills after grade 12 for a sustainable economy. In other countries, for example, Canada, technical skills training is meant to enhance the general education of students intending to join the labour force on leaving school. It offers industrial skills for youth who have completed high school and occupational skills for adults (Gardner \& Hill, 1999). The traditional pedagogy of workshop-type technical subjects was, and still is, in many cases, 'demonstration and follow' (Fritz, 1996); it has been used to good effect in the development of student competencies, particularly in industrial skills. However, technology education's evolution is transforming the subject from one that requires learners to imitate teacher-prescribed industrial hand- and machine-skills to one that is argued as being unique in the school curriculum (Walmsley, 2003). Technology education has been developed as a subject aimed at promoting an individual learner's ability to solve real-world problems by integrating specifically relevant knowledge of structures, materials, technological processes and systems (Department of Education, 2003).

Technology education is considered to be the panacea for South Africa's economic development and prosperity. The majority of learners in South African schools are subjected to a lack of exposure to technological products (for example, mechanical toys); hence, they lack experience in 'Do it yourself' (DIY) tools (Makgato, 2011; Martin, Dakers, Duvernet, Kipperman, Kumar, Siu, Thorsteinsson \& Welch, 2003). According to Galluzo (1996), there is no faith in the ability of teachers and existing schools to produce students who will excel in the industrial job market. In addition, a loss of confidence is fuelled by the belief that first, the present configuration of schools is incapable of producing youth who can meet the increasingly complex demands of the workplace, and second, the present school curriculum is outdated (Department of Education, 2000). All students who graduate from high schools should acquire the sustainable economic skills needed for employment, as well as, those skills required to continue the students' education (Makgato, 2011). The quality of technology 
education programmes is greatly determined by the number of students who acquire the skills for the economic development, knowledge and values needed by society (Makgato, 2011). It appears that the education system does not prepare children for a career after school, but merely a grade 12 certificate. School education is geared at making children job seekers and not job providers. In order to prepare job-providers for the country, the education system should make a significant paradigm shift by emphasizing hands-on technological skills that can sustain our economy at all levels of the school system (Makgato, 2011). The situation in South African schools still requires much attention, particularly with regard to equipping students with sustainable economic skills through quality technology education. Technology subjects are designed to respond to societal changes, such as those evident in many of the world's current post-industrial technological societies (Lauda, 1988).

Designing and making in technology education will make learners technologically literate. Learners will become more innovative, knowledgeable, skillful, adaptable and enterprising. This will enable learners to:

- Respond critically and resourcefully to challenges

- Devise creative ways of generating and applying ideas

- Translate ideas into worthwhile outcomes

- Find innovative solutions to community needs

- Focus on the design of techniques and products

- Deal with uncertainty in an informed way

- Cooperate in flexible teams

- Appreciate cultural differences

- Learn throughout their lives

- Use local, national, regional, and international networks (Rasinen, 2003).

The technological design process involves the application of knowledge to a new situation, resulting in the development of new knowledge. Technological design requires an understanding of the use of resources and engages a variety of mental strategies, such as problem solving, visual imagery, and reasoning. Developing these mental abilities and strategies so that they can be applied to problems is a significant aspect of technological literacy. These abilities can be developed in learners through experience in designing, modelling, testing, troubleshooting, observing, analyzing, and investigating (Walmsley, 2003). These types of skills provide learners with the opportunity and facility to fulfil the various requirements of the technological design process.

Bjurulf and Kirlbrink (2012) point out that in order to infuse theory into practice, teaching and learning should take place in different learning arenas, namely, both in schools and in workplaces. In schools, the workplaces may be referred to as practical laboratories or workshops. Bjurulf and Kirlbrink (2012) suggest that if schools cannot afford expensive machines, they enter into partnership with industries to teach specific course components in a workplace environment. Nze and Ginestie (2011) have discovered that the absence of 
equipment impels technology teachers to replace practical classes with those of a theoretical nature. They further affirm that equipment and its use are attributes of technology education.

Kennedy (2008) has observed that facilities like classrooms, workshops, laboratories, studios, equipment and materials are grossly inadequate in secondary schools. Bacchus (1988) warns of the fact that when equipment and materials are lacking, there is a tendency for the theoretical aspect of technology education to dominate the practical aspect, thereby denying technology education the opportunity to be taught qualitatively, and to take its rightful place in the education system. In support of the above, Ijambo (2001) believes that the lack of finance does not allow for practical subjects like technology education whilst Brunnete (2006) finds that technology education teachers and subsequently principals are frustrated by the lack of support from education offices in Namibia. Schools do not receive sufficient equipment and materials to teach technology practical subjects and the syllabus does not make provision for practical work either (ibid).

Gamble (2003) points out clearly that while practice cannot be substituted for theory, neither can theory be substituted for practice. Gamble concludes by stating that both theory and practice have their own place and that the one is impoverished without the other. According to the Department of Education in Papua New Guinea (Department of Education, PNG, 2006), the skills to be taught and learnt in the practical workshop are inclusive of the responsible and safe use of a range of tools, materials and techniques in the workshop. Reid and Shahi (2007) maintain that it is necessary for students to handle laboratory equipment regularly and that adequate time should be given to students to learn how to use equipment and to develop skills for practical activities. The Annual Report of the Namibia Ministry of Basic Education, Sport and Culture (MBESC, 2002) reports that many schools have only damaged tools or even no equipment at all with which to teach the subject effectively; schools have to use recycled materials and as a result syllabi are unfinished. A meeting of the Bureau of the Conference of Ministers of Education of the African Union (COMEDAF II, 2007) reports that offering practical sessions of technology education in schools is unlikely to be effective when delivered concurrently with general education subjects. This is because the practical component of technology education requires materials and extended time, both of which are too expensive to provide to all schools. Furthermore, the report explains that in general, the quality of training in Africa is low, with undue emphasis on theory and certification rather than on skills acquisition and proficiency testing.

\section{Workshop equipment and material factors for Civil Technology}

Civil Technology is a practical subject and according to Rosa and Feisel (2005), applying skills to everyday life requires both theory and hands-on workshop experience. While the former lends itself to classroom learning, the latter can be learned and practised only in the workshop. Working with materials and tools should lead to the development of manual skills, cognitive reasoning and the transference of these abilities to what has been designed in reality (Seiter, 2009). School workshops offer opportunities for the practical training of learners in skills acquisition in their technology education areas for the future development of key sectors of the economy in order to meet society's basic needs for electricity, roads and machinery, among others (Umar \& Ma'aji, 2010).

However, Mwaokolo (2003) affirms that the level and kind of training received by learners in technology education, in the workshop in particular, is quite different from what is required of them afterwards. In schools, the emphasis on skills acquisition, which is the hallmark of technology education, is an illusion. In the study, Mwaokolo maintains that most schools in 
Nigeria do not have workshops for practical lessons. There is no longer much emphasis on a learner's acquisition of practical skills.

The Windhoek Technical High School threatened to close down its workshops due to a lack of materials and old equipment that not only hampered practical work, but also increased the safety risk (Van Zyl, in Brunette, 2006). This is in contrast to the findings by Simiyu (2009) that in Kenya there is ample wood workshop space for practical lessons and that the machines are adequate for the number of learners studying civil technology subjects. In addition, the maintenance of equipment and machines is impeccable. Umar and Ma'aji (2010) assert that the availability of appropriate facilities enhances student learning by allowing students to be involved in demonstrations and to continue to build their skills through practice.

To illustrate this worsening situation, Puyate (2002) maintains that in Nigeria the present state of technology education facilities is very poor; there is no planned means to repair broken and damaged equipment or means of purchasing new equipment. This author adds that there is little or no concern on the part of government, teachers and students for the improvement of the present state of facilities. Anyakoha (1992) notes that the development of useful skills could be reinforced by the appropriate selection and use of learning facilities and resources. These facilities comprise workshop structures, working materials, teaching materials, workshop tools and equipment. In the same vein, Uzoagulu (1992) warns that where equipment and tools are not functional or where their provision is inadequate, technology training programmes will suffer and will lead to the production of unskilled personnel who are unemployable and unproductive.

Letsie (2003) in a contribution from a South African perspective, points out that as much as technology subjects offer an array of vocationally focused subjects with a practical orientation, most South African schools depend on theoretical studies with little access to technological facilities linked to apprenticeship. Skills development in the South African context has gone through many changes over the last decade, yet the skills development gap is still broad. South Africa is expected to be an active global player and tackle the burden of unemployment and poverty (Steinaker-Key, 2014). Technical high schools or comprehensive schools are expected to contribute to skills development through practical, hands-on vocational and technical education. So far, it is not very clear to what extent technological practical subjects at schools in South Africa produce skilled youth employable by various industries. Based on the critical needs for skills development and advocacy to train skilled youth, it is important to investigate the state of practical activities in technological subjects such as Civil Technology in selected schools in the Eastern Cape Province.

\section{Research problem statement}

The subject Civil Technology is taught from grade 10 to grade 12 and consists of both theoretical content and practical activities. Learners exiting grade 12 should have acquired adequate hands-on practical skills, according to CAPS. As part of assessment learners are expected to complete a PAT as evidence of their expertise in the practical component which counts for $75 \%$ of the examination requirements. Despite this PAT requirement, learners exit grade 12 of the Further Education and Training (FET) band in technology subjects with no hands-on practical competence or very limited competence in practical skills, as much of the literature has already confirmed. This is happening at a time when the country is desperately looking for youth who are technically skilled in order to solve the current youth unemployment problem and enhance South Africa's economic advancement. The practical activities at schools should form the basis for learners to become apprentices, artisans and 
technicians, particularly with regard to those learners who do not want to immediately proceed to higher education. This study is a significant contribution in the investigation of the state of practical hands-on activities in the subject of Civil Technology. The research questions below guide the investigation in order to understand the nature of this problem.

\section{Research questions}

This study has been guided by the following research questions:

1. How often do Civil Technology teachers teach practical sessions (if any) in schools?

2. What is the state of practical workshops in schools?

3. How are practical tasks and theory taught in the classroom?

\section{Theoretical framework}

The theoretical framework for the study was based on David Kolb's Learning Styles Inventory (KLSI) model and Experiential Learning Theory (ELT) as defined by Kolb (1984). ELT provides a holistic model of the learning process and a multi-linear model of adult development, both of which are consistent with what we know about how people learn, grow, and develop (ibid). Though Kolb's proponents view his model as too mechanistic and lacking in strong empirical validation, this study, however, views it as relevant as it is aimed at capturing the nature of learning through action. Hence, the theoretical framework chosen for this study is relevant because the study is based on the integration of theory to practical knowledge in the Civil Technology subject.

Kolb's learning theory sets out four distinct learning styles, which are based on a four-stage learning cycle (that might also be interpreted as a 'training cycle'). The four-stage learning cycle consists of (1) concrete experience (CE); (2) reflective observation (RO); (3) abstract conceptualization (AC), and (4) active experimentation (AE). CE occurs when learners experience active participation in the Civil Technology practical workshop, i.e. learners first see the project they are supposed to do in the workshop. $\mathrm{RO}$ is the stage when learners produce their own explanations from the drawing. Johnstone and Al-Shuaili (2001) are of the opinion that a student struggling to operate a piece of equipment may have failed to make important observations. $\mathrm{AC}$ is when learners conceptualize the principle relating to how the final product would look from the drawing. $\mathrm{AE}$ is a doing or performance stage, where learners are expected to manipulate equipment, materials and tools while taking safety issues into consideration. In relation to this study, Kolb's four learning styles involve the process which leads learners to understand, design and make the final practical model in the workshop. To be able to do this, learners are expected to conceptualize and put the project to be made in drawing form or, most importantly, to be able to interpret the project drawn on paper.

\section{Methodology}

Purposive sampling was used to identify 41 learners and three teachers to take part in the study. Data was collected through questionnaires for learners, interviews for teachers and the researcher's observation in the classroom which was adapted from the differentiated classroom observation scale protocol instrument derived from the study by Grant, Stronge and Popp (2008). According to Merriam (1998), the judgmental sampling technique is a 
sampling which identifies people who can provide the required information in response to the critical questions of the study.

All learners and educators involved with the subject Civil Technology in all three schools were respondents. The questionnaire data was analyzed using the SPSS statistical software. The analysis of results was in the form of frequency distribution. Interview data was first analyzed by transcribing. Each transcription was considered with the aim of identifying and underlining key issues. Descriptions were then formulated from the key issues identified as relevant to the study and coded. Themes were created and categorized into headings and narrated with the support of verbatim notes, while observation data was analyzed descriptively per item as reflected in the schedule. Each item on the observation schedule was analyzed per school with the purpose of finding a connection among the activities in the Civil Technology workshops in the three schools.

\section{Results and discussions}

The results of the study were presented in terms of three categories namely, questionnaire, interview and observation data.

\section{Overall questionnaire responses from learners}

Barriers to the teaching and learning of Civil Technology practical activities were listed in table 1 below where respondents answered as follows: Strongly Agree SA, Agree A, Disagree $\mathrm{D}$ and Strongly Disagree SD. Learners were requested to tick which item they agreed or disagreed with from the table.

Table 1: Workshop resources and skills acquisition as viewed by learners

\begin{tabular}{|l|l|l|l|l|}
\cline { 2 - 5 } \multicolumn{2}{l|}{ PERCENTAGES \% } \\
\hline $\begin{array}{l}\text { Workshop resources and skills } \\
\text { acquisition }\end{array}$ & SA (1) & A (2) & D (3) & SD (4) \\
\hline $\begin{array}{l}\text { There are not enough tools in the } \\
\text { workshop. }\end{array}$ & $22(54)$ & $16(39)$ & $1(2)$ & $2(5)$ \\
\hline $\begin{array}{l}\text { The tools we have are no longer in good } \\
\text { condition. }\end{array}$ & $18(44)$ & $15(37)$ & $2(5)$ & $6(15)$ \\
\hline $\begin{array}{l}\text { We do not have materials for practicals in } \\
\text { the workshop. }\end{array}$ & $11(27)$ & $19(46)$ & $3(7)$ & $8(20)$ \\
\hline $\begin{array}{l}\text { There is no machinery in the workshop. } \\
\text { (20) }\end{array}$ & $20(49)$ & $10(24)$ & $3(7)$ & $8(20)$ \\
\hline $\begin{array}{l}\text { We do not have access to the use of } \\
\text { machinery (if any) in the workshop for } \\
\text { practical projects. }\end{array}$ & $25(61)$ & $4(10)$ & $1(2)$ & $11(27)$ \\
\hline $\begin{array}{l}\text { We often prepare material (if any) on our } \\
\text { own for the project. }\end{array}$ & $13(32)$ & $3(7)$ & $15(37)$ & $10(24)$ \\
\hline $\begin{array}{l}\text { We do not do practicals weekly in the } \\
\text { workshop. }\end{array}$ & $33(81)$ & $6(15)$ & $1(2)$ & $1(2)$ \\
\hline
\end{tabular}

TD, 10(3), December 2014, pp. 323-339. 
There is more time allocated for practical $2(5)$

lessons weekly in the timetable.

Table 1 above indicates that the majority of learners (83\%) agree that the tools they have in the workshop are insufficient and that they have to share. Most (81\%) of the learners also agree that many of the tools they have are not in good condition. From the table, $73 \%$ of the learners agree that materials and machinery respectively are in short supply in their practical workshops. Puyate (2002) also finds that the present state of facilities in technology education is very poor, and there is no planned means of maintenance of broken equipment already in disrepair or means of purchasing new equipment. Puyate argues that there is little or no concern on the part of government, teachers and students for the improvement of the present state of facilities. When asked if they had access to and use of machinery in the workshop for their practical projects, $71 \%$ of learners agreed that they do not prepare the material on their own but teachers do that for them. The respondents $(86 \%)$ also agreed that they do not conduct practical sessions weekly in the workshop while $95 \%$ complained that the time they spent in the practical workshop is just too short. According to Brunette (2006), technology subjects must have practical work, as applying theory in practice provides the practical experience required by the work environment. This implies that learners leave grade 12 without adequate or practical hands-on skills. Brunette (2006) has also discovered that schools produce many learners without technical skills. The results indicate that learners are not doing the practical lessons as prescribed by the Civil Technology policy which advocates $1 \frac{1}{2}$ hours of time which is supposed to be spent by learners weekly in the workshop for practical lessons.

\section{Interview results and responses}

The analysis of interview data is presented and discussed in terms of the themes below, of which the first two themes tend to respond to research questions 1 and 2.

\section{The importance of workshop practical sessions for learners taking Civil Technology}

Teachers of Civil Technology consistently acknowledged the importance of workshop practical sessions for learners taking Civil Technology, as practice is an integral part of the subject. The respondents unanimously indicated that the practical component of the subject helps learners understand the theory of the subject. One theme that consistently emerged when the teachers responded to the issue of workshop practical sessions is that it is extremely important for learners to do practical work.

The respondents are of the view that learners should be able to become self-employed and create jobs on completion of grade 12 without any further training. However, teachers felt that the current training of learners does not offer them such opportunities.

The subject teacher from school A stated that the practical component covers a lot of material because it could train the learners to become self-employed, and also gives learners an opportunity for employment after grade 12 should they not further their studies. The subject teacher said:

For learners to make sense of the theory part, they have to go to the practical workshop to put what they have just learned into practice. Some of the learners who went through my hands at the school during the apartheid era are self-employed and make a living without any further training. 
This is reminiscent of Uwameiye's (1993:17) assertion that practical work constitutes an essential component of technology education.

\section{Challenges for teaching the practical component}

The study used interviews swith three Civil Technology teachers to determine the state of practical activities, in terms of teaching and learning in a practical workshop. This theme responds to research question two, to understand the state of the practical workshop at the schools. Each Civil Technology teacher from the three schools agreed that teaching the Civil Technology practical component is a laborious task. The teachers said that the challenges they face with regard to the practical component seem to have no solution.

Teacher C from School C was recorded saying:

Training material is a challenge; the government doesn't supply us with the material. Tools are expensive, machinery is old and to replace the machinery with the new is expensive. We end up levying the parents for us to be able to buy material for learners to be able to do practical. Generally the practical covers only what we have in terms of equipment which should not be the case as far as the syllabus and skills acquisition are concerned.

Then Teacher A from School A said:

We teach theory without the practical because we lack material and equipment. We do not even have a proper workshop for the practical lessons and this compromises the quality of what we are offering to learners in Civil Technology.

In response to the question of the state of practical workshops for Civil Technology the teacher from School B said:

The challenges we have concern the shortage of equipment and material as the government does not supply us with these materials and equipment. Although the government officials emphasize the importance of the practical skills when addressing the media, the reality is that we are practically suffering in schools. As a result, we are also lacking behind with the use of the latest modern technology equipment with regard to the practical component as no one from the government is concerned about the practical component of this subject. This happens despite the fact that technology changes all the time which necessitate that there be further training to keep abreast with technological development.

\section{Time for starting with the practical project for grade 12 class}

This theme responds to research question one which investigates the rate of conducting practical activities in the classroom at the three schools. Teachers stated that the practical was supposed to start earlier at the beginning of the year to give learners more time to practise skills. Teacher $\mathrm{C}$ said the following:

We were supposed to start at the beginning of the year to equip learners with practical skills, but because of the lack of material we do projects in the fourth quarter when moderation is about to take place just to meet the Civil Technology curriculum requirements for $P A T$ as opposed to skills acquisition. We rush the practical so that learners get the 25\% of the PAT. We are sent from pillar to post when we knock on provincial government doors asking about material and equipment for learners.

TD, 10(3), December 2014, pp. 323-339. 
In addition, the teacher B from School B had this to say:

The learners only get a chance to go to the practical workshop in September to prepare for PAT. Unfortunately this is the only time the school buys us material for the practical component.

The findings from the interviews with teachers indicate that the three schools are only interested in learners receiving the practical mark as opposed to mastering the practical skills.

The sentiments expressed above by these teachers echo the findings of Okorie's (2001) study on the dearth of tools in schools' technology education workshops and that the few tools that were available were obsolete, non-functional and did not meet the curriculum requirements. Uwameiye (1993) emphasises that practical work constitutes an essential component of technology education. This study further argues that without suitable workshop space, classrooms and laboratories, programme implementation and structuring would be very difficult if not impossible (ibid). However, this is in contrast to the findings by Simiyu (2009) that in Kenya there is ample wood workshop space for practical lessons, that the machines are adequate for the number of learners studying Civil Technology and that the maintenance of equipment and machines is elaborate.

\section{Learners' readiness to be entrepreneurs or work in industry after grade 12}

When teachers were asked whether learners acquire sufficient hands-on practical skills that meet the needs of technological industries, it emerged that the pattern of responses were similar. Teachers' respondents expressed the view that learners will not have acquired proper skills to become entrepreneurs or even work in industry after grade 12.

According to Osuala (2004), the shortage of equipment and materials for technology education impedes the training of students. Moreover, on completion of their schooling, these students have not acquired sufficient skills to enter the labour market. Teacher A from School A had this to say:

Our learners cannot get the skills to become entrepreneurs upon completion of their grade 12 because the training they get is not up to scratch. They are not getting the kind of skills which will make them become entrepreneurs after completion of their grade 12.The learners can only get the skills required for them to become entrepreneurs if they get further training. The advantage is that the learners stand a good chance to do Civil Engineering at Higher Education Institutions because of the built background they are exposed to. In the NCS learners do projects with cardboard and not with real material like in the old system. So this disadvantages them from dealing with what they should expect in reality.

Similarly, the teacher from School B said that the lack of material and equipment makes skills acquisition impossible as the time the learners spend in the workshop is too short to enable them to acquire the skills they need, given the fact that the school timetable does not even accommodate practical lessons.

\section{Observation results}

Non-participatory observations were made in the classroom at each of the three schools involved to answer all the RQs stated in the study. The observation schedule was underpinned by literature discussed as well Kolb's Experiential Learning Theory (Gamble, 2003; Kennedy, 2008; Kolb, 1999; Umar \& Ma'aji, 2010). In particular, the observation sought to investigate the state of practical workshops in schools and the teaching and learning 
of practical tasks, i.e. the integration of theory and practice in classrooms where Civil Technology is taught.

Arrangements were made earlier with both the head of department and principal in each sample school to conduct the observations. The observation data were analysed according to themes as presented and discussed below.

\section{Student's ability to use machinery}

On the learners' participation in the use of machinery, it was observed that learners were unable to use the available machinery in the workshop, because in all three schools the teachers would talk throughout the lesson without providing learners opportunity to conduct practical experiments. However, this could also be an indication of the teacher's inadequate competence to use the machinery. This is also confirmed by results from the questionnaire where learners disagreed that they often prepare materials for a project on their own. As Kennedy (2008) attests, this could be due to inadequate equipment and material in practical workshops at technical schools.

\section{State of the workshop}

The findings from the researcher's observations reveal that the state of the workshop in all three sampled schools is poor. This observation confirms the responses of the majority of learners and the teachers' responses that the workshops in the three sampled schools are in poor condition. Most machinery is broken and therefore remains dysfunctional. This is corroborated by Puyate's (2002) argument that the present state of technology education facilities is very poor as there are no planned means of maintaining the already broken equipment or avenues to purchase new equipment. In addition, there is little or no concern on the part of the government, teachers and learners for the improvement of the present state of facilities.

\section{Correct handling of tools}

Tools can be dangerous if not properly handled. They can cause serious injuries and even death because most of them are sharp. Few learners in all the sampled schools were seen to be handling tools properly as the majority of them did not follow the correct procedures.

Whether tools are in good condition or not, the handling procedure remains critical for safety reasons. According to the Department of Education in Papua New Guinea (DOE PNG, 2006), the skills to be taught and learnt in a practical workshop are inclusive of responsible and safe use of a range of tools, materials and techniques.

\section{Availability of equipment and material}

Notably, in all the workshops of schools A, B and C, the availability of equipment and materials is a problem. The findings from the researcher's observation are that in all three selected schools materials such as timber and safety gear are a great challenge.

Personal Protective Equipment (PPE), for example, safety goggles to protect the learners' and teachers' eyes from flying wood chips, dust masks to prevent inhalation of dust which might cause lung diseases, earmuffs to protect ears from being damaged by excessive noise coming from running machinery, safety gloves to protect hands from cuts, and safety clothing like boots and overalls, are in short supply. As argued by the National Union of Teachers (2011), for every kind of practical activity teachers should give priority to ensuring the availability and 
use of protective equipment. In short, safety should be a priority for teachers supervising practical activities.

PPE can be described as the equipment worn from head to foot in order to protect workers from injury and from contracting diseases in the workshop. Anyakoha (1992) argues that the development of useful skills can be reinforced by the appropriate selection and use of learning facilities and resources. These facilities, according to Anyakoha, comprise workshop structures, working materials, teaching materials, workshop tools and equipment.

\section{Teacher's demonstration on machinery}

For skills to be transferred, it is important that teachers demonstrate to the learners what needs to be done with the machinery. All teachers from the selected schools demonstrated a high level of knowledge on the use of the available machinery. However, the teacher from school B was seen operating machinery without protective equipment. Instead of using the mask to protect himself from inhaling dust, the teacher was observed to have inserted tissues into his nostrils. Though no teacher strictly followed safety and health measures, all knew how to use the available equipment. This contrasts with the assertion by Apagu and Andural (2007), namely, that school teachers lack knowledge and skills in the handicraft subjects because the curriculum used to prepare and train those teachers also omitted those aspects of education.

Umar and Ma'aji (2010) assert that the availability of appropriate facilities enhances student learning by allowing students to be involved in demonstrations and that, in addition, practice continues to build their skills. However, most technical colleges in Nigeria have been forced to perform below standard due to the purported non-availability, poor management or utter neglect of the required facilities in workshops for effective training.

\section{Status of equipment: tools and machinery}

This aspect was relevant to help check the status of the available equipment in workshops in the sampled schools. With this aspect the researcher established that some of the machinery is either in a poor condition if not broken or unused. This confirms the responses of the learners in table 1.4 and 1.6 where $80 \%, 5 \%$ and $73.2 \%$ of the learners respectively agreed that tools and machinery are not in good condition.

\section{Safety procedures}

The workshop can be a dangerous place to work in as it contains sharp objects and dangerous machinery. With regard to this variable, the researcher observed that in all the sampled schools, safety is considered only when machinery is operated simultaneously with the handling of tools. This then leaves both teachers and learners exposed to danger and health hazards. In all the selected schools learners, together with their teachers, were observed working without PPE.

Learners, as well as teachers, were observed to be working without PPE in a dusty and noisy environment created by the machinery. Notably, woodworking exposes workers to a variety of hazards, including kickbacks, flying wood chips, noise, wood dust and chemical substances. PPE can help protect against these hazards (National Union of Teachers, 2011).

\section{Infusion of theory into practice}

On this aspect, the researcher observed that because of the lack of material and equipment, integrating theory into practice is a challenge. Learners in all three sampled schools only go to 
the workshop around September for one month for the practical project. Although by that stage of the academic year students would have learnt a considerable amount of theory, they would find it extremely difficult, if not impossible, to incorporate this theoretical knowledge into practice in just one month.

The findings from this observation are corroborated by Bhurulf and Kilkbrink's (2012) argument that in bridging the gap between theory and practice, learners need to be taught theory or basic knowledge first before they can do practical lessons. It is argued that this will help them to transfer knowledge learned into practice. On the contrary, Mjelde (1995) argues that a sound approach in relating theory to workshop learning under present educational reform is that theory and practice should be learned at the same time.

\section{Conclusion and recommendations}

The questionnaires, interviews and observations from the three schools as discussed above have revealed that all the workshops lack equipment and material to equip learners with the technological skills required for a sustainable economy. The supply of tools to schools is contemptible as two of the three workshops in the selected schools lacked most tools, and the workshop in the third school had tools which in general were in such poor condition that they could not be used safely. From the selected schools in the study, it was discovered that there is no longer much emphasis on the learners' acquisition of the practical skills needed for a sustainable economy. The emphasis on skills acquisition, which is the hallmark for a sustainable economy, is in a dire state. It was found that no schools in the study had a technician competent to repair broken machinery; hence, any broken machinery is set aside to gather dust. The other common factor, which can be described as a great challenge, is that theory is taught for most of the available time because of the lack of materials as mentioned above. Because of this lack of equipment and material for practical lessons, learners spend most of the time in a theory class, therefore, the practical acquisition of skills is severely compromised. Moreover, it has been found in other studies (Makgato \& Mji, 2006) that the delivery of equipment and materials to schools does not necessarily guarantee that practical activities will be performed in class.

The findings also reveal that even in a situation where there is machinery in the workshop, learners do not have access to such machinery. It is possible that some teachers do not possess the appropriate skills to use the machinery, and they deem it dangerous for the machines to be used by learners. This practice of not allowing learners to handle machinery could be attributed to a lack of proper professional training for teachers.

In all three schools the study discovered that educators do the actual practical work for learners. This might also be caused by the fact that both educators and learners were pressed for time; they had to rush to complete the PAT project for moderation by officials of the Department of Basic Education. This factor is a blow to skills development on the part of the learners, because the focus seems to be on attaining marks for PAT rather than on skills acquisition. This practice denies learners the opportunity to get involved in their project from its foundation stages, thereby denying them the opportunity of manipulating and controlling tools and equipment to acquire the skills needed in a sustainable economy. The late arrival of material was also found to be a contributory factor to the failure of teachers to integrate the practical and theoretical components of the subject because of time constraints. Though both teachers and learners are aware of the importance of the Civil Technology practical component, it was discovered that in not one of the three schools were practical lessons timetabled. However, special arrangements are made towards the end of the year, usually 
around September, for learners to spend time in the workshop in order to complete the project for moderation. This means that learners do not have an opportunity to attend practical lessons on a weekly basis during the year. The basic principle of integrating theory and practice is that they should be timetabled together. These findings are supported by a meeting of the Bureau of the Conference of Ministers of Education of the African Union (COMEDAF II, 2007). The meeting reports that offering technology education practical in schools is unlikely to be effective because the practical requires time which is too expensive to provide in all schools.

Teachers should be thoroughly trained by HEIs to conduct practical activities with learners to equip them with marketable skills for entry into a sustainable economy after grade 12 . Technology teacher education and training should include regular exposure and visits to related industries in order for teachers to keep abreast with the latest technological developments. In its mathematics, science and technology strategy, the Department of Basic Education in South Africa should focus more closely on the development of technological literacy by equipping schools with relevant materials and equipment. It is also recommended that this department assign experts to be on call to attend to any eventuality which may arise from broken machinery in order to solve the current shortage of tools, materials and machinery. Apart from that, the department should as matter of urgency ensure the proper monitoring with respect to the offering of the subject throughout the year instead of only visiting the schools for PAT assessments towards the end of the year. Teachers at technical schools should be qualified and competent to conduct practical activities and, in addition, allow learners to conduct practical activities regularly to equip them with the required technical skills to compete in job markets. Regular exposure to the latest technological developments should be provided through learning new technologies using ICT and by visits to industry by both teachers and learners.

\section{References}

Aliyu, A.S. 1995. Laboratory skills: a prerequisite for effective agricultural Science teaching. Paper presented at Science Teachers Association Workshop.

Anyakoha, E.U. 1992. Development and utilization of facilities for Home Economics education program in Nigerian schools and colleges for manpower development. Nigerian Vocational Journal. 2(1):16-24.

Apagu, V.V. \& Andural, S.I. 2007. Refocusing Nigerian vocational education for relevance and sustainable development. Multidisciplinary Journal of Research Development. 9(1):December, 2007.

Bjurulf, V. \& Kirlbrink, V. 2012. Transfer of knowledge in technical vocational education: a narrative study in Swedish upper secondary schools. International Journal for Technology and Design Education. Springer Science Business Media.08 February, 2012.

Bacchus, K. 1988. The political context of vocationalisation of education in developing countries. In Lauglo, J. \& Lillis, K. (eds). Vocationalisation education: an international perspective. Oxford: Pergamon Press.

Brunette, H. C.2006. Technical education in Namibia: past trends, present circumstances and future prospects. PhD thesis: University of Free State. 
COMEDAF II (Bureau of the conference of the Ministers of Education of the African Union). 2007. Harmonization of higher education programmes in Africa: strategy for the African Union. Ethiopia: Addis Ababa.

Department of Education. 2005. National Curriculum Statement: Civil Technology (General) [Online]. Available from: www.education.gov.za.

Department of Basic Education. 2011. Curriculum Assessment Policy Statements (CAPS): Civil Technology. Available from:www.thutong.doe.gov.za/Resource download.aspx?

Department of Education, Papua New Guinea. 2006. Design and Technology Subject Field: Lower secondary syllabuses. Papua New Guinea: Department of Education.

Department of Education. 2003. Implementation of revised national curriculum (Grade R9). Pretoria: Government Printer.

Department of Education. 2000. National Curriculum Framework for Further Education and Training. Draft Document, Pretoria: Government Printer.

Department of Labour. 1998. Apprenticeships [Online].Available from www.labour.gov.za

Fritz, A. 1996. Reflective practice: enhancing the outcomes of technology learning experiences. The Journal of Design and Technology Education, 1(3):212-217.

Galluzo, G.R. 1996. The standards have come. Journal of Industrial Teacher Education, 34(1)11-13.

Gamble, J. 2003. Curriculum responses in FET Colleges [Online]. Available from: www.hrscpublishers.co.za.Pretoria: HSRC Press.

Grant, L., Stronge, J.H. \& Popp, P. 2008. Case studies of award-winning teachers forf at risk or bighly mobile students: what are the dispositions and behaviours of award-winning teachers . Journal of education for studies placed at risk, 16 (4): 275-291.

Ijambo, T.C.K. 2001. State, region, ethnicity and educational inequalities in post-colonial Namibia. Unpublished PhD thesis, Michigan State University.

Johnstone, A.H. \& Al-Shuaili, A. 2001. Learning in the laboratory; some thoughts from the literature. 17 September 2001.

Kennedy, O.O. 2008. Reappraising the workskill requirements for building technology education in senior secondary school for optimum performance in Nigeria. 3(2). IDOSI Publications.

Kennedy, O.O. 2011. Philosophical and sociological overview of vocational and technical education in Nigeria. American-Eurasian Journal of Scientific Research. 6(1).IDOSI Publications.

Kolb, D.A. 1984. Experientia learning: experience as the source of learning and development. Englewood Cliffs, N.J.: Prentice-Hall.

Lauda, D.P. 1988. Technology education. In Kemp W.H. \& Schwaller (eds.). Instructional strategies for technology education. Glencoe Publishing. England.

Letsie, L.E. 2003. Vocational-technical education and training in South Africa [Online]. Available from:http://upetd.up.ac.za/thesis/available/etd-0318200. 
Makgato, M. 2011. Technological process skills for technological literacy: a case of few technology teachers at schools in Tshwane North District D3, South Africa. World Transaction on Engineering and Technology Education. Vol 9 (2):119-124.

Makgato, M. \& Mji, A. 2006. Factors associated with high school learners' poor performance: a spotlight on mathematics and physical science. South African Journal of Education. 26(2):253-266.

Martin, D.J.,Dakers, J., Duvernet, L. Kipperman, D., Kumar, K., Siu, K.W.M., Thorsteinsson, G. \& Welch, M. 2000. In search of a sustainable future: an international overview of the contribution from design and technology education. Journal of Design and Technology Education. 8(3):137-149.

MBESC. 2002. Annual Report of the Ministry of Basic Education, Sport and Culture. [Online]. Available from www.nied.iiep.unesco.org.

Merriam, S.B. 1998. Qualitative research and case study applications. San Francisco: Jossey-Bas.

McGrath, S. 1998. National policies and institutional practices: the credibility gap in South African education and training reform. Journal for Vocational Education and Training. 50(4):503-518.

Mjelde, L. 1995. Activity pedagogy: how does it really work? In Heikkinen (ed.) Vocational education and culture: European prospects from theory to practice. Tampere: University of Tampere Press.

Mwaokolo, P.O.E. 2003. Related thoughts in vocational education. [Online]. Available from:www.searchworks.stanford.edu/view/5968659.

National Union of Teachers (NUT). 2011. Safety in practical workshops. [Online].Available from: www.teachers.org.uk.

Nwakile, I.C., \& Oloruntimehin, D. 2010. Problems and prospects of Nigerian educational system viz a viz teacher education programme. Journal of Qualitative Education. [Online] 6(1). Available from www.wesoedu.com.

Nze, J.S.B. \& Ginestie, J. 2011. Technical and vocational teaching and training in Gabon: how future teachers build their vocational identity. International Journal for Technology and Design Education. (22):399-416. 11 January 2011. Available from:http://www.springerlink.com/content/1547 x 2722ul.

Okorie, J.U. 2001. Vocational industrial education league of researchers in Nigeria. Bauchi.

Osuala, E.C. 2004. Foundations of vocational education. Enugu: Cheston Agency Limited.

Puyate, S. T. 2002. Survey of vocational education facilities in government technical colleges in Rivers State. Journal of Nigerian Association of Teachers of Technology.4(1):175-181.

Rasinen, A. 2003. An analysis of the technology education curriculum of six countries. Journal of Technology Education. 15(1): URL: http://scholar.lib.vt.edu/ejournals/JTE/v15n1/rasinen.html.

Reid, N. \& Shah, L. 2004. The roles of laboratory work in university chemistry. Chemistry Education Research and Practice. 4(1) 33-42.

Rosa, J. \& Feisel, L.D. 2005. The role of the laboratory in undergraduate engineering education. Journal of Engineering Education. January 2005. 
Seiter, J. 2009. Crafts and technology and technical education in Austria. International Journal for Technology and Design Education. 24 September 2009.

Simiyu, J. W. 2009. Revitalizing Training Institute in Kenya: A case study of Nairobi Technical Training Institute, Eldoret. Germany. UNESCO-UNEVOC International Centre for Technical and Vocational Education and Training.

Stainaker-Key, J. 2014. The challenging road ahead. Skills development: bridging the skills divide. Business Times. 18 May.

Umar, I.Y. \& Ma'aji, A.S. 2010. Repositioning the facilities in technical college workshops for efficiency: a case study of North Central Nigeria. Journal of Stem Teacher Education. 47(3).

Uwameiye, R. 1993. Some factors militating against the effective teaching of introductory technology in Bendel state schools. International Journal of Education Research. (5):1622.

Uzoagulu, A. E. 1992. Towards an effective equipment management (EEM) in schools for economic and technological self-reliance. Paper presented at the 7 th annual conference of the NVA held at FCE (T), Umunze. November 25-28.

Walmsley, B. 2003. Partnership-centered learning: the case for pedagogic balance in technology education. Journal of Technology Education. URL: http://scholar.lib.vt.edu/ejournals/JTE/v14n2/walmsley.html. 